\title{
FORMULASI SUPLEMEN KESEHATAN GRANUL INSTAN BERBAHAN BAKU TERONG BELANDA
}

\author{
Mira Miranti, Septia Andini, Bina Lohitasari \\ Program Studi Farmasi, FMIPA, Universitas Pakuan Bogor \\ Email :m2_miranti@yahoo.com
}

\begin{abstract}
ABSTRAK
Terong belanda merupakan bahan alam yang dapat digunakan sebagai suplemen kesehatan karena mengandung zat besi $(\mathrm{Fe}), \beta$-karoten, vitamin $\mathrm{C}$, senyawa antosianin dan serat pangan yang dapat mencegah kerusakan sel-sel jaringan tubuh, melancarkan penyumbatan pembuluh darah, menormalkan tekanan darah, menurunkan kadar kolesterol dan meningkatkan daya tahan tubuh. Penelitian ini bertujuan membuat formulasi suplemen kesehatan granul instan berbahan baku terong belanda dan mempelajari karakteristik fisik dan kimianya. Granul instant diformulasi dari ekstrak terong belanda dan sukralosa dengan tiga konsentrasi berbeda $(0,15 \mathrm{~g}$ sakralosa/25 g granul, $0,27 \mathrm{~g}$ sakralosa/25 g granul dan 0,39 g sakralosa/25 g granul) menggunakan metode granulasi basah. Parameter yang diuji meliputi karakteristik fitokimia ekstrak kering terong belanda dan uji mutu granul instan terong belanda. Hasil uji fitokimia menunjukkan bahwa ekstrak terong belanda mengandung flavonoid, tanin, saponin dan steroid. Hasil uji mutu granul instan menunjukkan bahwa granul instant dengan penambahan 0,27 g sukralosa/25 g granul lebih disukai panelis dibandingkan penambahan sukralosa dengan konsentrasi lainnya. Granul instan yang dihasilkan bersifat kohesif dengan waktu terdispersi 1 menit 34 detik, memiliki kadar air 3,78\%, kadar serat kasar 3,84\%, kadar serat pangan 12,58\%, kadar vitamin C 296,57 ppm, kadar antosianin 125,99 mg/L, kadar $\beta$ karoten 15,28 mg/100g dan kadar Fe 0,694 ppm. Berdasarkan hasil uji tersebut maka granul instan terong belanda memenuhi standar kualifikasi granul dan berpotensi sebagai suplemen kesehatan alternatif.
\end{abstract}

Kata kunci: Terong belanda, suplemen kesehatan, granul instan

\section{THE FORMULATION OF INSTANT GRANULE HEALTH SUPPLEMENT FROM TAMARILLO}

\begin{abstract}
Tammarillo, Solanum betaceum, is a rich source of natural nutrients such as iron, provitamin $\mathrm{A}$, vitamin $\mathrm{C}$, anthocyanin, $\beta$-caroten compounds and food fiber which act to protect the damage of body cell and tissue, reducing blood vessels blockage and lowering cholesterol levels. This study was aimed to formulate instant granule health supplement from extract of tomarrilo and various concentration of sucralose $(0.15 \mathrm{~g}$ sucralose $/ 25 \mathrm{~g}$ granule, $0.27 \mathrm{~g}$ sucralose $/ 25 \mathrm{~g}$ granule and $0.39 \mathrm{~g}$ sucralose $/ 25 \mathrm{~g}$ granule) using wet granulation method. The parameters tested including taste, physical and phytochemical characteristics. The results show that dried extract of tamarillo contains flavonoids, tannins, saponins and steroids. More over, instant granules formulated with addition of $0.27 \mathrm{~g}$ sucralose $/ 25 \mathrm{~g}$ granule sucralose was preferred than variations. The physical characteristic show the instant granule was cohesive with 96-100 seconds solubility in water. The granules have $3.78 \%$ of water content, $3.84 \%$ crude fiber, $12.58 \%$ dietary fiber, $296.57 \mathrm{ppm}$ vitamin $\mathrm{C}, 125,99 \mathrm{mg} / \mathrm{L}$ anthocyanin, $15.28 \mathrm{mg} / 100 \mathrm{~g} \beta$-carotene and
\end{abstract}


$0.694 \mathrm{ppm}$ Fe. From the overall results, it can be concluded that instant granule formulated from tamarillo extract meet the qualification standard of granule and has a potent as alternative health supplement.

Key words: Tammarillo, health supplement, instant granules

\section{PENDAHULUAN}

Nutrasetikal, dikenal juga sebagai pangan fungsional, medical foods, functional food, pharmafoods dan nutritional supplement, diartikan sebagai bahan alam dalam keadaan murni atau pekat, atau senyawa kimia bioaktif yang mempunyai efek meningkatkan kesehatan, mencegah penyakit atau mengobati penyakit. Food supplement atau suplemen kesehatan adalah produk yang dimaksudkan untuk melengkapi kebutuhan zat gizi makanan, mengandung satu atau lebih bahan berupa vitamin, mineral, asam amino atau bahan lain (berasal dari tumbuhan atau bukan tumbuhan) yang mempunyai nilai gizi dan atau efek fisiologis dalam jumlah terkonsentrasi. Suplemen dapat berbentuk sediaan pil, tablet, serbuk, granul, setengah padat dan cairan yang tidak dimaksud untuk pangan.

Penggunaan sediaan granul memiliki kelebihan dibandingkan bentuk sediaan suplemen lainnya, yaitu dalam hal kepraktisan dan kemudahan dalam penggunaannya. Bentuk granul biasanya lebih stabil secara fisik dan kimia daripada serbuk saja. Granul biasanya lebih tahan terhadap pengaruh udara. Selama granula lebih mudah dibasahi (wetted) oleh pelarut daripada beberapa macam serbuk yang cenderung akan mengambang di atas permukaan pelarut, sehingga granula lebih disukai untuk dijadikan larutan (Ansel, 1995).

Terong belanda merupakan salah satu bahan alami yang dapat dijadikan bahan baku food supplement karena kaya akan provitamin A (karotenoid) yang merupakan prekursor dari vitamin A yang bagus untuk kesehatan mata, Kandungan beta karoten dalam buah terong belanda terdapat $0,0710 \mathrm{mg}$ tiap $100 \mathrm{~g}$ bahan (Muhtadi, 2009). Kandungan pro vitamin A tersebut pada terong belanda memenuhi kebutuhan harian (RDI) vitamin A sebesar 13,15\%.

Terong belanda mengandung vitamin C sebesar $17 \mathrm{mg} / 100 \mathrm{mg}$ bahan. Kandungan vitamin $\mathrm{C}$ pada terong belanda memenuhi $27,44 \%$ RDI. Vitamin C berfungsi untuk meningkatkan daya tahan tubuh ataupun mengobati sariawan, dan berfungsi pula sebagai antioksidan (Idris et al., 2011).

Kandungan serat pada terong belanda sekitar $2 \%$ dan berdasarkan penelitian yang dilakukan oleh Lister, et al. (2005) diketahui kandungan serat 3,6 $\mathrm{g} / 100 \mathrm{~g}$ bahan yang bermanfaat untuk mencegah kanker dan sembelit. Terong belanda juga merupakan salah satu tanaman yang banyak dimanfaatkan oleh masyarakat sebagai obat untuk menurunkan kadar kolesterol darah. Berdasarkan penelitian Syariah, et al. (2011) diketahui bahwa pemberian jus terong belanda sebanyak 3,5 g/100 g bb tikus putih dapat menurunkan kadar kolesterol, sedangkan berdasarkan penelitian Idris et al. (2011) diketahui bahwa sari buah menurunkan kolesterol total darah pada tikus putih jantan pada konsentrasi 250mg/mL.

Terong belanda memiliki kandungan zat besi (Fe) sekitar 0,32 mg/100 g bahan (Idris et al., 2011). Tingginya kandungan $\mathrm{Fe}$ dan vitamin $\mathrm{C}$ dalam terong belanda berguna untuk mencegah anemia, dibuktikan dengan pemberian jus terong belanda konsentrasi $40-60 \%$ ternyata mampu meningkatkan kadar hemoglobin pada mencit anemia (Sianturi et al., 2012).

Antosianin termasuk kedalam golongan flavonoid yang memiliki 
aktivitas sebagai antioksidan. Ditinjau dari aspek fungsionalnya ternyata antosianin dalam buah terong belanda mempunyai khasiat sebagai sumber antioksidan alami. Antosianin dalam terong belanda memiliki aktivitas antioksidan sebesar IC 50 antara $196.8531 \mu \mathrm{g} / \mathrm{mL}-.240 .0811 \mu$ $\mathrm{g} / \mathrm{mL}$ (Armin et al., 2010) .Kandungan antosianin adalah 82,4 $\mathrm{mg} \mathrm{GAE} / 100 \mathrm{~g} \mathrm{FW}$ (Idris et al., 2011).

Berdasarkan uraian tersebut diatas, peneliti tertarik untuk melakukan penelitian membuat suplemen kesehatan dari buah terong belanda yang mengandung komponen bioaktif antosianin, serat, serta zat gizi berupa zat besi, vitamin $\mathrm{C}$ serta karotenoid dalam bentuk sediaan granul instan dengan metode granulasi basah. Tujuan dari penelitian ini adalah membuat formulasi suplemen kesehatan dari ekstrak terong belanda dan tiga variasi sakralosa kemudian menguji karakteristik fisik dan fitokimia granul yang dihasilkan serta menguji formula yang memiliki rasa paling disukai panelis.

\section{METODE PENELITIAN Alat dan Bahan}

Alat-alat yang digunakan alat gelas, moisture balance, blender, stopwatch, hot plate, vortex, oven, ayakan mesh 30, 12 dan 8, flowtester, freeze dryer, timbangan analitis, spektrofotometer UV-Vis, KCKT dan Kromatografi gas.

Bahan yang digunakan adalah buah terong belanda, sukralosa, laktosa, akuades, serbuk $\mathrm{Mg}, \mathrm{FeCl}_{3} 1 \%$ dan $0,1 \%$, $\mathrm{H}_{2} \mathrm{SO}_{4} 10 \%$, metanol, serbuk $\mathrm{Mg}, \mathrm{HCl}$, gelatin $1 \%, \mathrm{NaCl} 10 \%$, pereaksi Dragendroff, pereaksi Bouchardat, pereaksi Mayer, asam askorbat, $\beta$-karoten.

\section{Cara kerja}

\section{Pembuatan dan Pengujian Ekstrak Terong Belanda}

Sebanyak $5000 \mathrm{~g}$ sampel buah terong belanda dicuci dengan air mengalir hingga bersih, dipisahkan dari kulitnya dan dipotong-potong. Potongan buah selanjutnya dihaluskan menggunakan alat pembuat jus (juicer) sehingga diperoleh jus yang halus dan homogen. Kedalam jus ditambahkan maltodekstrin (10\%), diaduk merata kemudian dikeringkan menggunakan freeze dryer, sehingga diperoleh ekstrak yang kering dan beku.

Tahap berikutnya adalah uji karakteristik fisik ekstrak terong belanda meliputi penghitungan rendemen, analisis kadar air, analisis kadar abu dan uji fitokimia ekstrak meliputi identifikasi flavonoid, saponin, tanin dan alkaloid.

\section{Formulasi Sediaan Granul Instan}

Granul instan dibuat dengan metode granulasi basah. Ekstrak kering terong belanda yang telah ditimbang dan diayak dicampurkan dengan sukralosa, kemudian diaduk hingga terbentuk massa yang kompak. Selama proses pengadukan disemprotkan alkohol 70\%. Massa basah kemudian diayak menggunakan ayakan mesh 12 hingga terbentuk granul. Granul yang diperoleh dikeringkan didalam lemari pengering yang telah dialasi kain batis pada suhu $40-50^{\circ} \mathrm{C}$ selama \pm 2 jam sampai granul kering. Granul kering diayak menggunakan ayakan mesh 8. Formula granul instan ekstrak kering sari buah terong belanda dengan campuran sakralosa dapat dilihat pada Tabel 1 .

\section{Pengujian Sediaan Granul Instan}

Pengujian fisik sediaan granul instan meliputi: uji organoleptik (uji hedonik), uji kadar air, uji residu alkohol (kromatografi gas) dan evaluasi granul (uji aliran granul, uji sudut diam dan uji waktu terdispersi).

Analisis kimia ekstrak granul instan terong belanda meliputi: analisis kadar $\mathrm{Fe}$ (AAS), analisis kadar vitamin C (Metode KCKT), analisis kadar serat kasar (SNI 01-2891-1992), analisis kadar serat pangan, analisis kadar antosianin (metode 
pH-differensial) dan analisis kadar karotenoid (Spektrofotometri UV-Vis).

Tabel 1. Formula Granul Instan Ekstrak Kering Sari Buah Terong Belanda

\begin{tabular}{llll}
\hline \multicolumn{1}{c}{ Bahan } & Formula 1 & Formula 2 & Formula 3 \\
\hline EkstrakKeringTerong Belanda* & $14,4 \mathrm{~g}$ & $14,4 \mathrm{~g}$ & $14,4 \mathrm{~g}$ \\
Sukralosa & $0,15 \mathrm{~g}$ & $0,27 \mathrm{~g}$ & $0,39 \mathrm{~g}$ \\
Laktosa & $\mathrm{s} / \mathrm{d} \mathrm{25} \mathrm{\textrm {g }}$ & $\mathrm{s} / \mathrm{d} \mathrm{25} \mathrm{g}$ & $\mathrm{s} / \mathrm{d} \mathrm{25} \mathrm{g}$ \\
\hline
\end{tabular}

$*$ Berat per sachet $=25 \mathrm{~g}$.

HASIL DAN PEMBAHASAN

Karakterisasi Ekstrak Kering Sari Buah Terong Belanda

Ekstrak terong belanda yang dihasilkan pada penelitian ini memiliki kadar air dan kadar abu sesuai persyaratan Depkes RI yaitu 3,33\% untuk kadar air dan $2,45 \%$ untuk kadar abu. Demikian pula kadar air granul instan terong Belanda memenuhi persyaratan Depkes RI yaitu $3,78 \%$ sehingga mencegah pertumbuhan mikroba dan dapat memperpanjang masa simpan sediaan. Data diatas menunjukan bahwa kadar air granul terong belanda sedikit lebih tinggi dibandingkan kadar air ekstrak karena granul bersifat higroskopis.
Hasil karakterisasi fisik ekstrak kering sari buah terong belanda dapat dilihat pada Tabel 2.

Tabel 2. Karakteristik Fisik Ekstrak Kering Sari Buah Terong Belanda

\begin{tabular}{c|c}
\hline Parameter & Jumlah (\%) \\
\hline Kadar air & 3,33 \\
Kadar abu & 2,45 \\
\hline
\end{tabular}

Hasil uji fitokimia menunjukan bahwa ekstrak kering sari buah terong belanda mengandung flavonoid, tanin, saponin dan steroid. Hasil uji fitokimia ekstrak kering terong belanda dapat dilihat pada Tabel 3 .

Tabel 3. Hasil uji Fitokimia Ekstrak Kering Terong Belanda

\begin{tabular}{ccc}
\hline Identifikasi & Parameter & Serbuk Ekstrak \\
\hline Flavonoid & Merah Jingga & + \\
Tanin & Endapan Putih & + \\
Saponin & Terbentuk buih & + \\
Steroid & Hijau atau Biru & + \\
\hline \multicolumn{2}{l}{ Keterangan $:(+)$ = Positif mengandung golongan senyawa. }
\end{tabular}

\section{Karakteristik Granul Instan}

Granul instan terong belanda berwarna merah kecoklatan (Gambar 1) serta memiliki rasa asam manis dan aroma yang khas.

Dari hasil uji hedonik yang dilakukan terhadap 20 diketahui bahwa formula 2 lebih disukai dibandingkan formula lainnya dengan tingkat kepercayaan 95\%. Berdasarkan uji Duncan diketahui bahwa aroma dan rasa dari ketiga formula tidak berbeda nyata (disukai panelis). Hasil pengujian dapat dilihat pada Gambar 2.

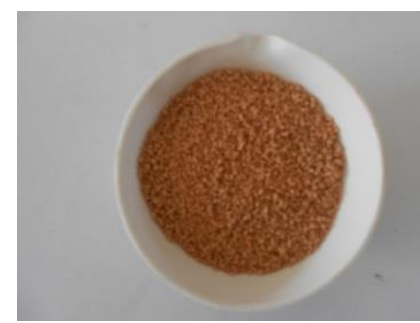

Gambar 1. Granul Instan Terong Belanda 


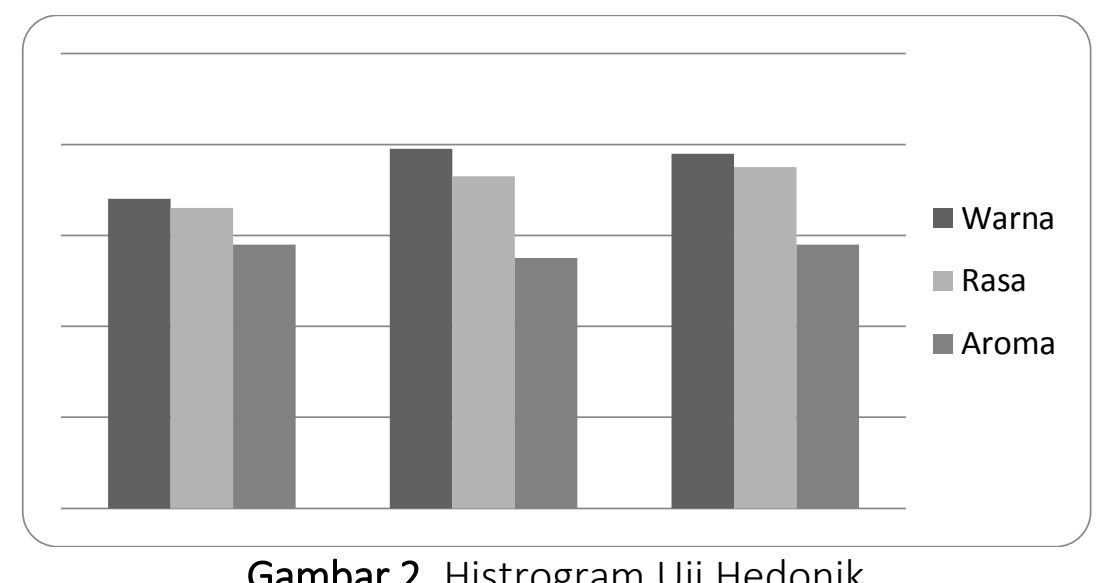

Gambar 2. Histrogram Uji Hedonik

Hasil pengujian terhadap waktu alir menunjukkan bahwa granul terong belanda bersifat kohesif sehingga tidak memenuhi standar granul yang ditetapkan oleh Aulton (1988). Sifat kohesif granul terong belanda disebabkan hadirnya zat aktif tertentu pada ekstrak terong belanda yang mempunyai sifat higroskopis yang mengakibatkan granul saling menggumpal sehingga memerlukan waktu alir yang cukup lama. Hasil uji sudut diam menunjukkan granul memiliki sudut diam $27,32^{\circ}$. Semakin kecil jumlah serbuk maka gaya tarik menarik antar partikel akan semakin kecil sehingga akan terbentuk tumpukan granul lebih mudah bergulir (Lachmanet et al., , 1994). Hasil uji kelarutan menunjukkan granul instan yang mengandung ekstrak kering buah terong belanda memiliki waktu dispersi 1 menit 34 detik (kurang dari 5 menit). Waktu larut merupakan salah satu sifat fisik sediaan granul instan yang khas, dimana sediaan granul instan yang baik memiliki waktu larut selama $<5$ menit. Hasil pengujian aliran granul, sudut diam dan waktu dispersi dapat dilihat pada Tabel 4.

Tabel 4. Hasil Evaluasi Granul

\begin{tabular}{lll}
\hline Pengujian & Hasil & Keterangan \\
\hline Aliran Granul & $3,42(\mathrm{~g} /$ detik) & Kohesif \\
Sudut Diam & $27,32^{\circ}$ & Mudah Mengalir \\
Uji waktu Dispersi & 1 menit 34 detik & Larut \\
\hline
\end{tabular}

\section{Hasil Analisis Kimia Ekstrak dan Granul Instan Terong Belanda}

Kadar air granul terong belanda berdasarkan hasil pengujian adalah sebesar 3,78\%. Menurut Lachmanet et al. (1994) kadar air granul instan adalah antara 2 4\%. Dari hasil pengujian residu alkohol menggunakan kromatografi gas diketahui bahwa pada granul instan tidak terdeteksi adanya alkohol.

Berdasarkan uji HPLC, didapatkan hasil bahwa pada ekstrak terong belanda memiliki kandungan vitamin C 508,59 ppm dan kadar vitamin $\mathrm{C}$ pada granul instan sebesar 296,57 ppm. Kadar vitamin $C$ pada sediaan granul instan mengalami penurunan dibandingkan kadar vit $\mathrm{C}$ pada ekstrak kering. Hal ini dapat terjadi karena pada proses dalam pembuatan granul terjadi pencampuran antara ekstrak dengan sakralosa sehingga konsentrasi vit $\mathrm{C}$ dan zat aktif lainnya akan berkurang. Pada 
proses pembuatan granul dapat terjadi oksidasi vitamin C karena asam askorbat bersifat sangat sensitif terhadap pengaruh luar yang menyebabkan kerusakan seperti suhu, $\mathrm{pH}$, oksigen, enzim dan katalisator logam. Vitamin $\mathrm{C}$ berfungsi untuk meningkatkan daya tahan tubuh ataupun mengobati sariawan, dan berfungsi pula sebagai antioksidan. Salah satu fungsi vitamin $\mathrm{C}$ adalah sebagai antioksidan. Di dalam tubuh, vitamin $\mathrm{C}$ dapat melindungi asam lemak tak jenuh rantai panjang, vitamin $\mathrm{E}$ dan vitamin A dari oksidasi. Vitamin $\mathrm{C}$ dapat meningkatkan absorbsi besi anorganik dengan membentuk suatu kelat yang dapat larut sehingga dapat diabsorbsi. Vitamin $\mathrm{C}$ membentuk kelat dengan besi pada $\mathrm{pH}$ lambung, sehingga meningkatkan absorbsi besi di usus. Bentuk ion besi yang dapat membentuk kelat adalah fero. Kemampuan vitamin meningkatkan absorpsi besi secara tidak langsung mempengaruhi pembentukan sel darah merah. Angka Kecukupan Gizi (AKG) rata-rata yang dianjurkan untuk anak-anak sekitar 30-45 mg sehari, untuk pria dan wanita dewasa sekitar 65-90 mg sehari,untuk wanitahamil terjadi penambahan $10 \mathrm{mg}$ sehari,dan untuk wanita menyusui terjadi penambahan $10-25 \mathrm{mg}$ sehari (Depkes RI, 2000).

Hasil pengujian kadar serat kasar dan serat pangan dalam ekstrak sari buah terong belanda sebesar $6,680 \mathrm{mg}$ per $100 \mathrm{~g}$ dan $10,82 \mathrm{mg} / 100 \mathrm{mg}$, sedangkan serat kasar dan serat pangan yang didapat dalam sediaan granul instan adalah masingmasing sebesar $3,840 \mathrm{mg}$ per $100 \mathrm{~g}$ dan $12,58 \mathrm{mg} / 100 \mathrm{mg}$. Serat kasar (crude fiber) adalah komponen sisa hasil hidrolisis suatu bahan pangan oleh asam kuat dan basa kuat seperti $\mathrm{H}_{2} \mathrm{SO}_{4}$ dan $\mathrm{NaOH}$ (kehilangan sekitar $50 \%$ selulosa dan hemiselulosa $85 \%$, residu terbesar lignin. Serat pangan (dietary fiber) adalah kelompok polisakarida dan polimer-polimer lain yang memiliki sifat tidak dapat dicerna dan diserap oleh sistem gastro-intestinal bagian atas tubuh manusia (tahan terhadap enzimenzim pencernaan), beberapa komponen dapat difermentasi oleh mikroflora dalam usus besar. Serat pangan memiliki kecenderungan untuk membentuk gel dengan air dengan viskositas berbeda, sebagai prebiotik yang dapat difermentasikan oleh bakteri-bakteri yang terdapat dalam usus besar manusia (terutama inulin) dan memiliki efek kesehatan pada pencernaan, penurunan kadar kolesterol, penurunan penyerapan glukosa dari makanan. Kebutuhan serat berkisar antara 20-35 g sehari.

Pengukuran kadar antosianin menggunakan spektrofotometer UV-Vis dengan metode $p H$ differential diperoleh kadar antosianin dalam ekstrak buah terong belanda adalah sebesar 45,72 mg per $100 \mathrm{~g}$. Nilai kadar ekstrak menunjukkan nilai yang lebih rendah bila dibandingkan dengan penelitian yang dilakukan oleh Lister et al (2005), yaitu sebesar 82,4 mg per $100 \mathrm{~g}$, hal ini disebabkan perbedaan bahan baku yang diuji seperti varietas yang berbeda. Kadar antosianin yang diperoleh dari sediaan granul instan adalah sebesar $12,71 \mathrm{mg}$ per $100 \mathrm{~g}$. Kadar $\beta$-karoten yang didapat pada ekstrak buah terong belanda adalah sebesar 42,6 mg per 100 g. Kadar $\beta$ karoten pada granul adalah sebesar 15,8 $\mathrm{mg} / 100 \mathrm{~g}$, terjadi penurunan kadar disebabkan ekstrak yang ditambahkan dalam jumlah sedikit dan terjadi kontak langsung dengan udara pada saat pembuatan. Berdasarkan hasil pengujian diketahui bahwa ekstrak sari buah terong belanda mengandung kadar $\mathrm{Fe}$ sebesar 1,164 ppm dan dalam granul instan sebesar $0,694 \mathrm{ppm}$.

\section{SIMPULAN DAN SARAN}

Dari hasil penelitian dapat disimpulkan bahwa terong belanda berpotensi sebagai suplemen kesehatan yang dapat diolah menjadi granul instant dengan cita rasa yang disukai panelis. Granul instan terong belanda juga memiliki 
karakteristik fisik yang memenuhi standar kualitas DepKes RI.

Perlu dilakukan penelitian selanjutnya untuk menguji stabilitas dan masa simpan granul instan dan uji farmakologis untuk mengetahui efek-efek yang lebih spesifik dari sediaan granul instan terong belanda.

\section{UCAPAN TERIMAKASIH}

Ucapan Terimakasih disampaikan kepada DP2M DIKTI yang telah memberikan dana penelitian Hibah Dosen Pemula.

\section{DAFTAR PUSTAKA}

Ansel, H.C. 1995. Pengantar Bentuk Sediaan Farmasi Edisi keempat. Penerjemah F. Ibrahim. UI Press: Jakarta.

Armin, F., Y. Dewi dan M. Mahyuddin. 2010. Penentuan kadar senyawa fenolat dan uji aktivitas antioksidan pada buah terung belanda (Cyphomandra Betacea (Cav.) Sendtn) secara spektrofotometri visibel. Jurnal Higea. 3 (1): 1-15.

Aulton, M.E. 1988. The Science of Dosage from Design. Churchill Livingstone: Endiburg.

Departemen Kesehatan RI. 2000. Parameter Standar Umum Ekstrak Tumbuhan Obat. Direktorat Pengawasan Obat dan Makanan. Jakarta.

Idris, I.W., U. Usmar dan B. Taebe. 2011. Uji efek hipokolesterolemik sari buah terong belanda (Cyphomandra betaceae Sendt.) pada tikus putih (Rattus norvegicus). Majalah Farmasi dan Farmakologi. 15(2): 105-110.

Lister, C.E., S.C. Morrison, N.S. Kerkhofs, dan K.M. Wright. 2005. The nutritional composition and health benefits of New Zealand tamarillos. Crops \& Food Research Confidential Report No. 1281. New Zealand
Institute for Crop \& Food Research Limited. Christchurch-New Zealand. Muhtadi D. 2009. Pengantar Ilmu Gizi. Alfabeta. Bandung.

Musfiroh, M., W. Indriyati, M. Muctaridi dan Y. Setiya. 2012. Analisis Proksimat dan Penetapan Kadar $\beta$ karoten dalam Selai Lembaran Terung Belanda (Cyphomandra betaceae Sendt.) dengan Metode Spektrofotometri Sinar Tampak. Diunduh dari http//www.pustaka.unpad.ac.id.

Sianturi, S., M. Tanjung dan E. Sabri E. 2012. Pengaruh buah terong belanda (Solanum betaceum Cav.) terhadap jumlah eritrosit dan kadar hemoglobin mencit jantan (Mus muculus L) anemia strain DDW melalui induksi natrium nitrit (NaNO2). Saintia Biologi. 1(2): 4954.

Syariah, W.O, U. Usmar dan S. Rahmawati. 2011. Pengaruh jus buah terong belanda (Cyphomandra betaceae Sendt.) terhadap kadar kolesterol total tikus putih (Rattus norvegicus) jantan. Majalah Farmasi dan Farmakologi.15(2): 95-98. 
